\title{
Democracia e partidos políticos: nexo conceitual e sua manifestação na consolidação do Estado de partidos brasileiro
}

\author{
Democracy and political parties: conceptual nexus and its manifestation in the \\ consolidation of the Brazilian State of Parties
}

Democracia y Partidos Políticos: nexo conceptual y su manifestación en la consolidación del Estado de partidos Brasileños

Orides Mezzaroba* Marjorie Carvalho de Souza*

\section{Resumo}

Com o propósito de provar o nexo teórico entre democracia e partidos políticos na moderna sociedade de massas, o trabalho apresentado se debruça sobre essas duas figuras da Ciência Política, descrevendo-as desde sua conceituação, apontando as causas dessa conexão e as funções que as agremiações desempenham nesse regime de governo. Deslocando a investigação para o plano empírico, a experiência política brasileira é narrada com ênfase na trajetória dos Partidos até sua ampla recepção pelo ordenamento jurídico, a fim de corroborar o paralelo entre a institucionalização dos Partidos e o fortalecimento da democracia. A última etapa desse processo - a adoção da democracia plebiscitária no moderno Estado de partidos - coincide com a última seção do artigo, na qual a análise se concentra no confronto entre os requisitos da doutrina majoritária para a efetivação desse modelo, e a conjuntura política e jurídica atual do Brasil - no derradeiro esforço de demonstrar em que direção aponta a consolidação da democracia brasileira.

Palavras-chave: Democracia. Partidos Políticos. Estado de partidos.

Doutor em Direito. Professor Associado com dedicação exclusiva nos Programas de Graduação e Pós-Graduação em Direito (Mestrado e Doutorado) da Universidade Federal de Santa Catarina. E-mail: oridesmezza@gmail.com.

** Graduanda no curso de Direito da Universidade Federal de Santa Catarina. Pesquisadora Bolsista do Programa Institucional de Bolsas de Iniciação Científica (Pibic/CNPq).

Recebido em 17/11/2014 - Aprovado em 25/03/2015 http://dx.doi.org/10.5335/hdtv.15n.1.5282 


\section{Introducão}

Apesar das aparentse universalidade e hegemonia com que o regime democrático se consolidou no horizonte político do Ocidente pela massiva adesão dos países a esse modelo e que serviria, supostamente, para provar o sucesso de sua exportação pelas nações pioneiras às demais vizinhas, essa hipótese resta inexoravelmente refutada pela especificidade da história das instituições descrita em cada país.

Ainda que batizadas sob a mesma denominação, as práticas políticas observadas nas diversas comunidades democráticas do hemisfério Oeste do globo são resultado de processos particulares de formação histórica e amadurecimento das instituições, que, gestados a ritmos diversos, culminaram em organizações políticas singulares adaptadas a complexos sociais próprios.

Levando isso em conta, um estudo autêntico sobre a atual conjuntura em que se assenta o Estado de partidos em gestação no Brasil, principalmente no que concerne à sua previsão constitucional e legal, ainda que enriquecido pela confrontação e delineamento de paralelos com institutos equivalentes em seus pares do Ocidente, há que considerar a história política específica do país para compreender a trajetória percorrida pelos partidos até sua ampla recepção pelo ordenamento jurídico.

Antes de mergulhar nesse mérito, entretanto, urge apontar de que forma os partidos políticos são indispensáveis para a realização da democracia numa sociedade de massas. A fim de explicar tal associação aludida entre eles, a primeira seção deste trabalho debruça-se a destrinchar essa analogia.
Para tanto, a investigação neste ponto é conduzida por dois aspectos: o primeiro destinado a assinalar as causas que fundamentam a preferência pelos partidos políticos como o instrumental da consumação da democracia mediada, e o segundo a apontar as funções específicas que eles desempenham numa democracia consolidada.

Feitos esses apontamentos, a segunda seção dedica-se à trajetória dos partidos políticos no Brasil, delineada desde a pré-história das agremiações, no Período Imperial, até o momento de sua mais ampla incorporação ao aparato estatal com o advento da Constituição Federal de 1988. Nessa triagem, são feitas observações pontuais que relacionam a experiência política do Brasil com a afirmação de que os partidos políticos são essenciais à realização da democracia, buscando confirmar essa intrínseca relação.

Por fim, o último tópico tratará da conceituação do terceiro modelo democrático de representação política instrumentalizado pelos partidos - sucessor da Democracia Representativa (liberal) e da Democracia Representativa Partidária - denominado Estado de partidos. Após conceituar esse novo paradigma de organização política, e sustentar sua imprescindibilidade para a realização da democracia moderna, serão confrontadas as legislações brasileiras com os requisitos elencados pela doutrina majoritária para a efetivação desse modelo, a fim de demonstrar qual é o ambiente jurídico e político em que o Brasil se encontra hoje no que tange à recepção e efetivação de um Estado de partidos. 


\section{Nexo conceitual entre partidos políticos e democracia}

Toda investigação teórica que se debruça sobre o estudo das organizações partidárias e do regime político democrático esbarra na conexão intrínseca entre essas duas figuras emblemáticas na Ciência Política desde a etapa de conceituação de cada uma delas. A democracia, considerada na sua realidade contemporânea como espaço político das massas (MEZZAROBA, 2004, p. 11), de faceta representativa e carente de mediação política, encontra, nos partidos políticos, seu instrumento de realização. Afinal, para que o ideal democrático se concretize de forma a permitir o acesso de todos os cidadãos da comunidade política às decisões do governo, são necessárias organizações que aglutinem ideologias e aspirações sociais semelhantes conferindo-lhes representatividade.

Dessa forma, o papel de intermediação entre representantes e representados passa a ser desempenhado pelos partidos políticos na atual etapa de experiência democrática das sociedades de massas. Cabe a eles, portanto, refinar os interesses particulares inserindo-os numa visão mais ampla, isto é, num programa político. A representação política visa, harmonizando os interesses dos indivíduos, a realizar a igualdade. Por conta disso, é necessário que os partidos estabeleçam quais categorias estarão predominantemente contempladas, para que os indivíduos se identifiquem e se reconheçam plenamente representados no exercício da atividade legislativa. Tendo em conta a responsabilidade da função de determinar a política nacional, torna-se imperativa essa filtragem das aspirações individuais (ZAMPETTI, 1969, p. 2).

Todavia, é pertinente assinalar a ressalva apontada por Mezzaroba (2004, p. 155) ao comentar essa relação entre democracia e partidos políticos, em que ele chama atenção para a insuficiência da presença do instituto da representação política em determinado país como garantia democrática, uma vez que até Estados não democráticos contam com essa estrutura. O que torna um Estado democrático de fato não é a mera atuação de partidos como órgãos mediadores do cidadão junto às instâncias políticas, mas o comprometimento deles com a efetivação da democracia, que, aliado ao seu potencial de promover a participação e representação dos eleitores, é capaz de tornar um Estado plenamente democrático e acessível aos anseios da população.

Para ilustrar essa afirmação, Mezzaroba recorre ao exemplo do regime ditatorial que vigorou no Brasil de 1964 a 1985, em que, apesar de legalmente funcionarem partidos políticos, as instituições democráticas do país eram intensamente sufocadas.

De todo modo, se as organizações partidárias por si só não são indicativo de democracia, não há como esse regime se concretizar se não por intermédio delas, uma vez que só por meio de seu potencial de congregação é que os eleitores tornam-se grupos capazes de ação política. Se não por intermédio desses legítimos porta-vozes, a massa amorfa não estaria em condições de dar fôlego aos órgãos do poder estatal.

Nesse contexto, a compreensão doutrinal e a regulação jurídica são apresentadas por García-Pelayo (1986, p. 40-41) em duas 
vertentes: a primeira considera-os como direitos subjetivos públicos e a segunda como fator constitutivo da estrutura democrática objetiva. Em ambas - tanto a que considera uma atualização do direito subjetivo de associação quanto a que considera como entidades objetivamente necessárias para a vigência da ordem democrática - a ofensa a esses significa uma lesão à própria Constituição, restando protegidos, dessa forma, por uma garantia institucional.

Gambino (2009, p. 7) classifica os partidos políticos como peças fundamentais para chegar à identificação da forma de Estado e de seu modelo organizativo, a forma de governo. Tanto uma como a outra já não podem ser definidas, para o autor, em termos abstratamente fixos, mas como partes do direito constitucional vivo.

Mergulhando mais a fundo na fundamentação da analogia entre partidos e democracia, cumpre direcionar a análise do estudo por dois aspectos: as causas que fundamentam a preferência pelos partidos políticos como o instrumental por excelência da consumação da democracia representativa e as funções específicas que esses desempenham numa democracia consolidada.

Fatores justificantes da primazia dos partidos políticos como meio privilegiado de realização da democracia

García-Pelayo (1986, p. 73-74) enumera dois fatores que contribuem para a preferência:
I. Massificação da conquista dos direitos democráticos associada ao crescimento populacional da sociedade e à extensão do direito ao sufrágio concedido agora a toda população adulta, incluindo estratos segregados de outrora como as mulheres e os despossuídos.

Nesse ponto, cabe destacar um adendo apontado por Zampetti (1969, p. 149-153), que chama atenção para a insuficiência da cessão do direito a voto a todos os cidadãos como condição probatória da vigência da soberania popular. Levando isso em conta, infere-se que representação política eletiva e soberania popular não são equivalentes.

O princípio da soberania popular - alicerce do Estado democrático - começou a se afirmar quando a todos os cidadãos, independentemente de sua posição econômica e social, foi concedido o direito de voto, de forma a substituir o regime restritivo que vigorava para outro fundado no sufrágio universal. Todavia, para que essa garantia seja operante, é necessário que exista um nexo recíproco entre concessão de poderes e participação dos indivíduos em seu exercício. Do contrário, essa prerrogativa não passa de uma etapa para o alcance da soberania, uma vez que ela é um ponto de chegada, cujo alcance só se dá por meio de uma série de estágios determinados pela evolução da realidade histórica e das demandas sociais.

Para tornar-se concretamente soberano, o povo precisa exercer efetivamente o poder, isto é, não apenas eleger os representantes, mas participar com eles do poder, de modo a adequar cada vez mais a vontade 
popular à atuação do Estado. Entretanto, o enorme número de eleitores e sua incapacidade para estimar programas múltiplos e para conhecer diretamente aos candidatos torna indispensável recorrer a um mediador entre uns e outros, cabendo aos partidos políticos facilitarem essa participação. Vale destacar que esse posto é próprio dos Estados democráticos e requer sensibilidade para apreender os interesses dos particulares que os compõem e compatibilizá-los com o interesse geral.

Quanto a essa exigibilidade dos partidos como mediadores, Leibholz traça um prognóstico concordante ao afirmar que, na democracia de hoje, só eles estão aptos a unir os cidadãos em grupos capazes de ação política, ao que alude à metáfora proferida pelo Tribunal Constitucional Federal alemão, que compara sua atuação para o povo com a de um alto-falante, em que os eleitores se expressam articuladamente e adotam decisões políticas. Para o autor, se não houvesse esse elemento interposto, o povo não conseguiria exercer influência política sobre o Estado, nem realizar-se politicamente. Pela sua definição precisa: "Na democracia moderna, se não existissem os partidos, o povo não faria outra coisa que vegetar politicamente, impotente e sem ajuda" (1980, p. 206-207).

II. Estruturação da sociedade atual a partir de organizações, de forma que a consecução de objetivos só se realiza através de mediação.

García-Pelayo (1986) descreve essa conjuntura como parte do fenômeno histórico resultante da já citada massificação da sociedade, a que levou a um crescimento quantitativo de demandas e contribuiu para a falibilidade de estruturas tradicionais, a serem substituídas por outras mais adaptadas à satisfação de novas necessidades e valores nos distintos campos de desenvolvimento social. Especificando a abordagem para a seara política, o povo amorfo só consegue se manifestar, se materializado pela atuação dos partidos com seu potencial organizativo.

De outro modo, Leoni (1990, p. 284) aponta causas distintas que motivariam um indivíduo a afiliar-se a alguma agremiação:

I. Participação ideológica: consiste na tentativa de contribuir para uma determinada ideologia por meio da adesão a um partido, constituindo um tipo especial de afiliado: fidelíssimo, para quem o partido torna-se um instrumento para a realização de determinados objetivos antes de ser uma entidade válida em si mesma.

Nesse sentido, os partidos políticos seriam organizações propostas a manter ou conquistar o poder em função de uma interpretação determinada, isto é, ideológica, da realidade. Esse grupo, portanto, é fruto da reunião de cidadãos com ideias afins que tenham o objetivo de garantir "influência eficaz na marcha da vida pública" (KELSEN, 1980, p. 197).

II. Participação instrumental: significa a tentativa de buscar objetivos pessoais ou coletivos extrapolíticos por meio da adesão a um partido.

III. Participação formativa: É o tipo de adesão típico dos jovens, os quais veem no partido o lugar no qual é 
possível acrescentar seus próprios conhecimentos, formar opiniões e enriquecer sua bagagem cultural e política.

IV.Participação socialitária: a sede do partido funciona como lugar de reunião e convivência dentre os membros.

Funções desempenhadas pelos partidos no regime democrático

Diretamente relacionadas aos motivos fundantes recém-citados, cabe assinalar as funções típicas dos partidos nas democracias consolidadas. Montero e Gunther (2002, p. 15) assinalam recrutamento de candidatos, mobilização do apoio eleitoral, estruturação das agendas políticas e formação de governos. No entanto, cabe a García-Pelayo (1986, p. 75-84), novamente, uma abordagem mais aprofundada desse tópico, na qual ele descreve os seguintes papéis:

I. Movimentar as massas para sua participação e inclusão no processo democrático, de forma a diminuir as abstenções no exercício do sufrágio a níveis toleráveis que não deslegitimem a democracia, tendo em vista que o abstencionismo é favorável na medida em que diminui as pretensões ao poder e revela a estabilidade do sistema, já que mostra que não se objetam opções tão contraditórias. Todavia, quando o número de abstenções resulta muito expressivo, pode significar falta de adesão, indiferença e repulsa, representando perda de legitimidade democrática. De qualquer forma, resta provada a importância dos partidos políticos para concretizar a razão de ser do sistema democrático, quais sejam: participação e integração dos cidadãos na vida pública, as quais, ao mesmo tempo, segundo o autor, constituem condição para a consciência de sua legitimidade.

II. Receptar e dirigir ações políticas em uma dupla-face de atuação. A primeira vertente se manifesta pela transformação de orientações e atitudes políticas gerais de certos setores da sociedade em programações de ação política nacional, convertendo as necessidades expressas ou difusas do conjunto da população em pretensões precisas e concretas a serem satisfeitas pelos poderes públicos. $\mathrm{O}$ segundo flanco corresponde ao papel desempenhado por dirigentes políti$\cos$ da sociedade, liderando ações políticas e solicitando demandas para os cidadãos, não se limitando a apenas receber orientações. Nesse ponto, o autor chama atenção para a necessidade de flexibilidade ideológica das linhas orientadoras dos partidos para que se adaptem às demandas políticas da sociedade em uma dada conjuntura, de forma a maximizar os benefícios políticos.

III. Sistematizar as demandas sociais em programas de ação coerentes com as prioridades a que se propõem, estabelecendo, assim, inter- 
-relações e coesão entre elas, a fim de inspirar as decisões do Estado.

IV.Formular e expor seus programas em linguagem acessível e compreensível à média da população, especialmente aos setores sociais a que se orienta preponderantemente. Entretanto, essa simplificação de problemas complexos não deve ocultá-los, mas, sim, esclarecê-los.

V. Proporcionar aos eleitores a oferta de listas de nomes viáveis à eleição.

VI.Oferecer aos eleitores seu potencial organizativo, capacidade de articulação de uma pluralidade de recursos humanos e materiais voltados à consecução de objetivos. Neste caso, os alvos consistem em satisfazer certas demandas ou orientações do eleitorado.

Com base nos fatores expostos, a existência de partidos solidamente organizados representa condição essencial para realizar, na maior medida possível, as tendências dos eleitores e para cumprir com as exigências e os requisitos da democracia na época de massas.

\section{Trajetória dos partidos políticos no Brasil}

Uma vez provada a conexão inerente entre partidos políticos e democracia, cumpre expor a trajetória que eles percorreram no Brasil e o papel que desempenharam no tortuoso caminho de construção da democracia desde a Independência do país. Ao descrever essa digressão teórica da evolução do regime jurídico e constitucional dos partidos políticos no ordenamento brasileiro, é possível perceber a história política do país implícita nesse processo. Afinal, conforme observa Vieira:

A origem e o tipo das organizações partidárias que surgiram no país estão intimamente relacionados com o modelo de colonização e o tipo de Estado implantado (2002, p. 65).

O ponto de partida desta seção concentra-se no período Imperial, compreendido entre os anos 1822 e 1889, nos primeiros tempos de vida independente da nação brasileira. De encontro ao tratamento dispensado pelas manchetes jornalísticas da época que denominavam os grupos políticos de partidos, a doutrina majoritária posiciona-se na opinião de que naquele período tais organizações não passavam de simples associações políticas, distantes da conotação atual assumida pelos partidos políticos. Tratava-se de meras facções e grupos de interesse que parasitavam a coroa (CHACON, 1985, p. 23).

Dividiam-se em três correntes distintas (resultantes da fragmentação dos emancipacionistas e colonialistas do período Colonial): monarquistas, moderados e radicais, que se organizaram para participar da Assembleia Geral Constituinte. Contudo, sua atuação foi interrompida pelo primeiro golpe brasileiro de Estado: o fechamento do Congresso com a outorga por D. Pedro I da nova Constituição. Essa tendência absolutista e de concentração de autoridade do imperador, materializada no Poder Moderador instituído pela Carta de 1824 (BRASIL, 1824), inviabilizava os projetos de organização partidária e resumia a importância des- 
ses grupos a meros parasitas em disputa à sombra do trono. De outro modo, o próprio reinado restou prejudicado por essa postura de D. Pedro, chegando ao fim com a sua abdicação em 1831 (VIEIRA, 2002, p. 70-71).

Esse vácuo de poder deixado pelo imperador é preenchido pela ascensão de regentes que se revezaram no governo do país até 1840. Durante esses nove anos, estando temporariamente afastada a fiscalização do Poder Moderador, surgem no Brasil Independente as primeiras tendências de opinião estáveis, identificadas por princípios políticos semelhantes, mas que careciam de um ambiente jurídico propício para receber a alcunha legítima de partidos políticos.

De modo semelhante, essas organizações funcionaram durante o Segundo Reinado, capitaneado pela figura de D. Pedro II, jovem recém-emancipado, de modo que meramente estão fincadas as origens das organizações partidárias, mas sem que por meio delas tivesse vigência um sistema representativo ou uma democracia partidária de fato. A estrutura imperial e o espírito elitista do regime e dos burocratas da época afastavam as funções precípuas dessas agremiações, reduzindo-as "a partidos de quadros ou de notáveis, de formação nitidamente interna" (NASPOLINI, 2006, p. 138), que pouco se diferiam entre si, embora se identificassem por ideais opostos - liberais e conservadores. Aos personagens desse quadro político, a cultura popular cunhou a expressão, que sintetiza magistralmente o vazio ideológico dessas associações quando no exercício do poder, "farinhas do mesmo saco".

Apesar do discurso de ruptura e progresso, a proclamação da República em 1889 não veio alterar esse cenário hostil à proliferação dos partidos políticos. Pelo contrário, convencidos de que a culpa da ruína do regime imperial era das divisões originadas pelas organizações "partidárias" existentes, muitos dos republicanos que chegaram ao poder cultivavam uma mentalidade antipartidária (VIEIRA, 2002, p. 75). A essa repugnância acrescente-se a apatia política da população, que esteve alheia ao processo revolucionário, como outro fator prejudicial ao associativismo político na República que se iniciava (NASPOLINI, 2006, p. 138).

Essa postura gerou reflexos na Constituição promulgada em 1891 (BRASIL, 1891), na posterior legislação ordinária da República velha - silentes em matéria de partidos políticos - e na própria história republicana, marcada pela concepção de que os partidos eram entraves à implantação da democracia que a elite política pretendia instalar, quando na verdade constituíam empecilhos apenas para o oligopólio que caracterizou a cúpula do governo do país à época.

Mesmo nesse ambiente hostil às associações políticas, alguns setores da sociedade, como a classe operária, tentaram se reunir a fim de aventar representação nacional, mas foram rispidamente reprimidos e perseguidos, inclusive por meio de leis que se pretendiam mantenedoras da ordem, da moralidade e da segurança pública, mas cujo único resultado fora coibir movimentos sociais que ameaçassem a ordem. Os militares, fortalecidos pela proclamação da República, constituíram um partido peculiar, com reconhecimento da sociedade e autoridade suficiente para não se sentirem intimidados em desrespeitar a ordem constitucional e legal do país. 
A Presidência da República só é ocupada por um civil a partir de 1894, pelo presidente Prudente de Morais. Nessa época, a política da nação estava descentralizada pelos focos de poder dos grandes fazendeiros em seus celeiros eleitorais. Os agrupamentos existentes não passavam de facções oligárquicas cuja representatividade alcançava apenas os interesses das elites de cada Estado-membro da federação.

O quadro institucional dos partidos políticos, nesse período pouco democrático de revezamento camarada entre os coronéis na direção do país, era organizado por lei civil $^{1}$ (BRASIL, 1916) como pessoas jurídicas de Direito Privado em virtude da não previsão legal de sua existência. Insurgindo-se contra esse sistema, consuma-se por golpe militar um movimento revolucionário em 1930, capitaneado por diversos estratos insatisfeitos da sociedade.

Essa conquista entusiasmou a população ao sinalizar para o início de uma nova era sob a liderança de Vargas que superaria as oligarquias da República Velha. Entretanto, o que pareceu ruptura não passou de mera conciliação. No sintético e preciso diagnóstico de Vieira: "trocaram-se os atores, mas permaneceram os velhos vícios de representação da Primeira República" (2002, p. 84).

Em pouco tempo, o titular do governo provisório, Getúlio Dorneles Vargas, deixou transparecer suas tendências, centralizadora e fascista, suprimindo os partidos estaduais e concentrando todo o controle do país de forma autoritária na esfera nacional. Essa ação de manifesta despreocupação com a ordem constitucional deu causa ao levante constitucionalista de 1932, desencadeado em São Paulo, cujo mérito - apesar da derrota nos campos de batalha - foi apressar o fim do governo revolucionário com a convocação da Constituinte.

Com vistas a esse processo, um ano depois, em 24 de fevereiro de 1932, foi promulgado o primeiro Código Eleitoral do Brasil, no Decreto $n^{\circ} 21.076$ (BRASIL, 1932), que reconheceria pela primeira vez a existência jurídica dos partidos brasileiros (art. 99) e regulamentava seu funcionamento (art. 100). Com a nova lei, passavam a ser considerados partidos políticos três espécies de agrupamento: permanentes, provisórios e associações de classe. Some-se a isso a possibilidade de registrar candidaturas avulsas, o que parecia um avanço em termos de reconhecimento, figura, na verdade, como um duro golpe ao funcionamento dessas organizações, dada a possibilidade de surgir uma bancada apartidária sujeita ao controle permanente do presidente sem a imunidade da "livre ação dos partidos". Esse fato apenas confirma a tese de que o governo de Vargas inclinava-se à centralização autoritária e ao esforço de deslegitimar os partidos políticos (MEZZAROBA, 2004, p. 199).

Vale destacar, contudo, que antipartidarismo não era prerrogativa exclusiva do presidente. Pelo contrário, foi um pensamento preponderante da época, refletido na composição da Assembleia Constituinte - em que, apesar de múltiplos os partidos, eram inexpressivos e desprovidos de credibilidade - e na Constituição aprovada em 1934, que os recepcionou como meras correntes de opinião. Com efeito, partidos políticos fortes e representativos permaneceram ausentes, apesar de a tentativa de preencher 
esse vazio político ser liderada pelos polos oposicionistas - Aliança Nacional Libertadora (ANL) e Ação Integralista Brasileira (AIB) - associações políticas que tinham alguns traços partidários.

Se a essa altura a democracia brasileira já se encontrava extremamente prejudicada, a partir de 1937 o sistema político do país sofre mais um duro revés. A pretexto de combater uma revolução comunista fajuta, encenada por um colaborador do próprio governo Vargas, o presidente outorga a Constituição conhecida pela alcunha polaca (dada sua inspiração polonesa e fascista) e inaugura o Estado Novo, com a decretação do estado de emergência, seguido do estado de guerra. Em todas as esferas da federação, o Parlamento foi dissolvido, e com ele qualquer hipótese de livre representação política, além do propósito de instaurar um governo forte e centralizador ter sido claramente reafirmado.

Sob a alegação de proteger o Brasil de se tornar prisioneiro de um partido ou facção que não o próprio povo, é baixado o Decreto-Lei $n^{\circ} 37$ (BRASIL, 1937), extinguindo todos os partidos políticos inscritos nos tribunais da época. O texto constitucional, apesar de silente quanto às organizações partidárias, inviabilizava qualquer iniciativa nesse sentido. Apesar desse combate, o próprio governo sentiu a necessidade de criar uma organização que o sustentasse politicamente, o que deu origem à criação da Legião Cívica Brasileira, em 1938 (MEZZAROBA, 2004, p. 205). Contudo, esse projeto enfrentou resistência do estrato militar, sendo imediatamente desarticulado. "Se não conseguiu estabelecer o partido único, o governo do Estado Novo, no entanto, não se esqueceu de suprimir todos os outros" (MELO FRANCO, 1980, p. 73).

Destarte, o governo que se iniciou pretendendo-se revolucionário apenas reeditou o autoritarismo, de oligárquico a populista. Entretanto, esse regime torna-se insustentável diante da derrota das potências fascistas na Europa e na Ásia, que o Brasil inclusive ajudara a combater. Diante das pressões da sociedade civil, o governo Vargas prepara o processo de transição para o regime democrático de modo a preservar seu nome para um eventual retorno ao Palácio do Catete. Ele o faz por meio do Decreto-Lei $\mathrm{n}^{\circ} 7.586$ (BRASIL, 1945), conhecido como Lei Agamenon Magalhães, que regula o funcionamento dos partidos políticos e regulariza os trâmites para as eleições do final daquele ano.

A Quarta República, portanto, à medida que se democratiza, torna o ambiente jurídico mais favorável aos partidos políticos. Com aquele dispositivo, "inaugura simultaneamente no Direito Brasileiro os controles quantitativos e qualitativos ou ideológicos sobre as agremiações partidárias" (NASPOLINI, 2006, p. 144), materializados nas exigências de: a) atuação em âmbito nacional; b) aquisição de personalidade jurídica sob a lei civil; c) apoio de, pelo menos, dez mil eleitores, distribuídos em um mínimo de cinco Estados. As hipóteses de cassação, embora pouco democráticas, não minimizam seu caráter pioneiro, quais sejam: quando os partidos não elegessem pelo menos um representante para o Congresso Nacional ou não atingissem o patamar de cinquenta mil votos nacionais e se seus programas atentassem contra a democracia ou os direitos 
fundamentais do homem, conforme a Constituição que seria elaborada.

É válido destacar, contudo, que nem todos os obstáculos ao pleno desenvolvimento da democracia partidária foram retirados por este decreto-lei. $O$ fato de permitir a inscrição dos candidatos em múltiplas legendas e candidaturas simultâneas a cargos diferentes e em vários Estados, por um mesmo político, contribuía para o processo de personalização do voto e da política, além do enfraquecimento dos partidos menores. Esse fato é apontado por Naspolini (2006, p. 145) como hipótese mais nociva ao sistema partidário do que as candidaturas avulsas do governo provisório, já que de um lado incentivava a instituição dos partidos, mas de outro, impulsionava o surgimento de lideranças individuais, que fatalmente entrariam em confronto, cujo resultado seria mais prejudicial aos primeiros.

Outra proibição, na sequência, com a Assembleia Nacional Constituinte já em funcionamento, é acrescentada ao rol de restrições legais e serve de fundamento legal para a cassação do registro do Partido Comunista Brasileiro, bem como do mandato de todos os seus membros: a vedação de recebimento por parte das agremiações de recursos financeiros ou orientação ideológica provenientes de nações estrangeiras.

A Constituição dos Estados Unidos do Brasil, de 1946, acena de forma mais amistosa às instituições partidárias, referindo-se, pela primeira vez na história constitucional republicana, de forma explícita aos partidos políticos, regulamentando-os em consonância com a legislação ordinária precedente, instituindo novas prerrogativas, destacan- do-se, principalmente, por enunciar o pluripartidarismo como princípio essencial da ordem política.

Nesse novo cenário jurídico - não obstante a mentalidade resistente e a precariedade das instituições -, houve consideráveis ganhos quanto à participação política popular, bem como à estruturação dos próprios partidos. Dentre as múltiplas novas associações, três alcançaram maior repercussão política: o Partido Social Democrático (PSD), a União Democrática Nacional (UDN) e o Partido Trabalhista Brasileiro (PTB). Em um panorama sintético e preciso, todos os partidos políticos do período são fruto de articulações elitistas, incapazes de promover a legítima representação nacional por meio de novas lideranças. Apesar da proliferação das exigências quantitativas enquanto mecanismos legais de contenção da multiplicação partidária, os verdadeiros vícios do sistema não foram combatidos, como a manutenção das velhas forças políticas no poder. Entre os anos de 1945 e 1964, as instituições políticas continuaram precárias, bem como a representatividade do sistema, uma vez que as renovações política e jurídica não alcançaram os elementos mais nocivos da política no país: seus personagens e seu modus operandi.

Antes de consolidar-se, entretanto, essa experiência democrática foi abortada. Em 1964, outro golpe de estado vem romper a ordem constitucional com a pretensão de "proteger" a nação da "ameaça comunista". Dessa vez, os militares avocaram para si a missão e, investidos de poderes arbitrários, suprimem a já precária democracia brasileira. Para narrar o período, são extraídos al- 
guns dados da dissertação de Vieira (2002, p. 98-109).

Dentre o rosário de boas intenções do governo militar, constava recuperar os partidos políticos de sua decomposição legada pela Quarta República. Com esse objetivo, foram promulgados, em 1965, um novo Código Eleitoral ( $\left.\mathrm{n}^{\circ} 4.737 / 1965\right)$ e a primeira Lei Orgânica dos Partidos Políticos ( $\left.\mathrm{n}^{\circ} 4.740 / 1965\right)$, cujos efeitos imediatos foram a cassação de 63 deputados e a manutenção de apenas cinco agremiações, decorrentes da inclusão de novas exigências qualitativas para o registro de partidos. Todavia, a permanência dos remanescentes foi breve, três meses depois eles foram extintos pelo Ato Institucional $\mathrm{n}^{\circ} 2$ (BRASIL, 1965). Apesar de não impedir a criação de novas agremiações para manter a legitimidade do regime, o governo enrijeceu os critérios de formação - interferindo inclusive na escolha dos nomes - a fim de dissolver a força que gozavam as siglas tradicionais.

Nesse período vigorou um bipartidarismo, que projetava a ideia de normalidade política por meio da Aliança Nacional Renovadora (Arena) e do Movimento Democrático Brasileiro (MDB). Na prática, a primeira era formada por representantes da elite do governo e a segunda uma oposição consentida, que meramente flechava algumas críticas construtivas sem jamais obter vitórias significativas.

Em 24 de janeiro de 1967, é promulgada a quinta Constituição republicana, que trouxe nova abordagem acerca dos partidos políticos, com a inclusão dos critérios mais rígidos da história política brasileira visando à Constituição legal de agremiações, dada a exigência de robusta representatividade em pelo menos dois terços dos Estados da Federação. Essa rigidez ratificou de vez o bipartidarismo, tornando inviável o registro de qualquer outra agremiação.

Mesmo que de forma autoritária e sufocante, até então houvera sido preservada a aparente legalidade do sistema. Porém, ante a contestação do regime pela sociedade civil, por meio de passeatas e greves, os métodos de terror foram intensificados. Esta fase tem início com a decretação do famigerado Ato Institucional $\mathrm{n}^{\circ} 5$ (suspensor do habeas corpus e concessor de poderes ilimitados ao chefe do Executivo nacional) e do Decreto-Lei $n^{\circ}$ 898, a Lei de Segurança Nacional. Nesse processo de endurecimento da ditadura instaurada, a própria Constituição de 1967 é amplamente reformada pela Emenda Constitucional $\mathrm{n}^{\circ} 1$, em 1969, incorporando ao novo texto os pressupostos dos dois dispositivos recém-promulgados.

No que concerne aos partidos políticos, mantiveram-se severos requisitos para seu funcionamento, com a inclusão do critério fidelidade partidária, que previa punição para os parlamentares infiéis. Essa hipótese era providência premeditada pelos próprios militares para retaliar dissidentes dentro do próprio partido do governo, a Arena. De toda sorte, a autonomia dos partidos para reger suas estruturas internas não existia, $\mathrm{e}$ essa postura de controle foi coadunada pela nova Lei Orgânica dos Partidos Políticos de $1971\left(n^{\circ} 5682 / 1971\right)$.

Nos anos seguintes, o arrocho ditatorial se intensificou por meio de leis claramente voltadas para uma engenharia política disposta a manipular inescrupulosamente 
as eleições em favor dos interesses militares. Proibição de divulgação de propostas em programas eleitorais, eleições indiretas, sublegendas, cargos biônicos, foram alguns dos recursos utilizados pelo governo na tentativa desesperada de se manter no poder.

Ao final da década de 1970, entretanto, já era possível visualizar algumas medidas no sentido de uma abertura lenta, gradual e negociada do regime militar para o civil. A intenção era fragmentar e enfraquecer a oposição, mesmo que o custo dessa estratégia fosse a volta ao multipartidarismo. Por meio da Emenda Constitucional $n^{\circ} 11$ (BRASIL, 1996), algumas regras para a criação de partidos foram alteradas, de modo a facilitar o surgimento de novas agremiações. Seus efeitos, contudo, não valeram para o pleito de 1978.

Com a revogação do AI-5, e a promulgação da Lei da Anistia (para amigos e inimigos do regime) naquele mesmo ano, inúmeras lideranças exiladas retornaram ao país e à cena política, aproveitando esse cenário favorável à criação de novas organizações partidárias. A abertura definitiva veio por meio da Lei ${ }^{\circ}$ 6.767, em dezembro de 1979, editada pelo último presidente militar da ditadura: João Batista Figueiredo. Da extinção da Arena e fragmentação do MDB, surgiram seis partidos políticos, dos quais apenas a única legítima novidade, perante a desgastada concepção tradicional da política brasileira, foi o Partido dos Trabalhadores (PT), oriundo do movimento sindicalista paulista.

Os derradeiros esforços de manipulação das eleições, investidos pelos militares, consistiram numa reforma eleitoral, editada em janeiro de 1982, com o estabelecimento do voto vinculado. A medida era manifestamente direcionada a favorecer o PDS, partido que substituíra a Arena como agremiação vinculada ao governo, e tornou ainda mais difícil para os novos partidos alcançar o quociente eleitoral, ocasionando a necessidade de prorrogação do prazo de obtenção de votos para que as novas legendas se regularizassem.

De todo modo, o sentimento de insatisfação popular com o regime e o anseio pela redemocratização atingiam proporções cada vez maiores, materializando-se na tomada das ruas por manifestantes e pelo surgimento do movimento Diretas Já!. Apesar da massiva adesão de vários setores da sociedade civil e política, a Emenda Constitucional Dante de Oliveira, que propunha a institucionalização de eleições diretas, não obteve no Congresso o quociente de votos necessário para sua aprovação.

A transição para a democracia, portanto, teve de ser realizada de forma negociada, conciliando os interesses entre as elites dirigentes, além de atender à estratégia do governo militar de operar o processo lenta e gradualmente. Desse conluio, a solução articulada foi a eleição de Tancredo Neves para a Presidência da República, fruto de um acordo entre o PMDB e dissidentes do PDS, sendo que esses indicaram o candidato a vice, José Sarney, ex-presidente da Arena.

O já combalido processo de redemocratização, contudo, recebe novo golpe, desta vez desferido por uma infelicidade do destino. Tancredo morre antes de ser empossado, legando a José Sarney a árdua tarefa de coordenar a transição do regime 
militar para o civil, sua posse, apesar de ter a legalidade contestada, se realiza em 1985.

Nessa nova conjuntura política, coube reformar, também, as normas referentes aos partidos políticos, tornando-as mais favoráveis à criação e ao funcionamento de novas agremiações. Com esse propósito, foi promulgada em 15 de maio de 1985 a Emenda Constitucional $n^{\circ} 25$. Apesar de manter a exigência de quocientes mínimos de votação, essa alteração na lei permitiu que as entidades com registros indeferidos se reorganizassem, de forma que nas eleições para o Congresso Constituinte, em 1986, fossem registradas quase trinta organizações partidárias (MEZZAROBA, 2004, p. 228).

A mentalidade antipartidária, entretanto, ainda era uma tônica no país, dada a falta de tradição política nesse sentido. Sob essa motivação, alguns estratos da sociedade se mobilizaram para defender a tese da candidatura avulsa na constituinte. Por ser matéria controversa entre os congressistas, mas cara ao regime democrático que se pretendia consolidar com a nova Constituição, o tema foi objeto de acalorados debates entre os membros das comissões, sendo o dispositivo constitucional referente aos partidos o que sofreu maior número de alterações no curso do processo (NASPOLINI, 2006, p. 154-155).

Apesar do consenso quanto à necessidade política dos partidos, dois polos de opinião opunham-se no que concerne à abordagem que a Constituição deveria dispensar a essas organizações, repousando a dúvida sobre a regulamentação do Estado perante os partidos: mais ou menos intervencionista e restritiva?
Corroborando o entendimento apresentado neste trabalho até aqui e a experiência política do próprio país, prevaleceu a ideia de que para consolidar os valores que a sociedade ansiava e que os congressistas haviam sido eleitores para defender, como a democracia, a liberdade e o pluralismo econômico, social e político, eram necessários partidos políticos fortes e livres, que gozassem de autonomia para se organizar.

Fiel a esse propósito, são incluídos no texto legal os sustentáculos da democracia brasileira, por meio da institucionalização da garantia de autonomia e liberdade partidária - princípio da autodeterminação dos partidos políticos -, e a inclusão da filiação a um partido político como condição de elegibilidade. Com esse mérito, a Constituição cidadã de 1988 entrou para a história partidária do país como a Carta Brasileira de redação mais liberalizante. Estavam lançadas as sementes para o enraizamento de uma verdadeira democracia partidária.

\section{Estado de partidos como o novo paradigma de organização política no Brasil}

Entendendo o nexo conceitual entre partidos políticos e democracia, e após provar historicamente essa premissa pela trajetória política brasileira, cabe agora expor o que é um Estado de partidos e como o Brasil, com a consolidação de sua democracia pelo advento da Constituição de 1988, criou o ambiente jurídico favorável para sua adoção. 
Democracia de partidos como o terceiro modelo de representação política democrática

Na sua gênese, quando instaurada por Clístenes em Atenas no século VI a. C, a democracia enquanto regime político permitia a participação ativa de todos os cidadãos da pólis - ainda que a cidadania fosse uma noção mais restrita naquela época. Diante do aumento demográfico e territorial dos Estados modernos, esse arranjo tornou-se inviável, sendo necessárias adaptações para a sobrevivência do modelo ao longo da história.

Isto posto, cabe listar as fases evolutivas da Democracia, segundo a proposta doutrinária de García-Pelayo (1986, p. 8283), para efeitos didáticos: a) Democracia direta - caracterizada pela ausência de mediação política e deliberação direta do grupo social, podendo ser ilustrada pelo modelo ateniense; b) Democracia representativa - expressa o pensamento liberal clássico, marcada pela dualidade entre representante e representado, sendo válida juridicamente apenas a vontade expressa do primeiro; c) Democracia representativa partidária - a mediação entre aqueles dois polos no exercício do poder passa a ser desempenhada pelos partidos políticos; d) Democracia Partidária (ou Estado de partidos) - objeto deste estudo.

Em reconhecimento à autoridade do autor no tema, é pertinente reproduzir integralmente a definição precisa de García-Pelayo sobre Estado de partidos: "é o resultado da articulação e interação entre o sistema de partidos e o sistema estatal de nosso tempo" (1986, p. 11). Nesse modelo, conforme o magistério elucidativo de Mezzaroba (2004, p. 155), os representantes estão vinculados a um mandato partidário, submetidos à vontade única e exclusiva do partido, conferindo à eleição um caráter plebiscitário, já que o eleitor outorga a sua confiança ao partido como organização, e não aos candidatos.

Recorrendo a outro teórico importante dessa expressão moderna da democracia, são listadas, a seguir, algumas das consequências estruturais básicas apontadas por Leibholz (1980, p. 210-227) decorrentes da adoção do modelo. A primeira delas diz respeito à essência e forma do Estado de partidos, que nada mais é, segundo o autor, do que uma manifestação da democracia plebiscitária, da qual resulta que a vontade popular ou geral é gestada pelos partidos pelo princípio da identificação, não da representação. Sob esse novo paradigma, os projetos internos da Assembleia tornam o papel do público, ao mesmo tempo, complementário e decisivo, tendo em vista que ordena ao processo de integração da democracia de partidos.

Uma das implicações desse sistema seria o reposicionamento funcional do parlamento, que se converteria num mero posto de reunião dos comissionados dos partidos para registro das decisões tomadas em suas sedes e conferências. Os parlamentares, nesse contexto, transformam-se em "máquinas de votar" subjugadas aos dirigentes dos partidos.

Leibholz (1980) se refere a esse fenômeno como um deslocamento do centro político de gravidade do parlamento aos cidadãos e aos partidos que o organizam, destacando o fato, entretanto, de que as comissões parlamentárias ainda seguem desempenhando 
importante papel. Com essa transferência, o parlamento se transforma profundamente e perde sua posição-chave, outrora ocupada no aparato do poder estatal, sendo seu antigo poder de decisão quanto à legislação e rumos decisivos do país assumido, a partir de agora, pelos partidos.

Tal prognóstico também se aplica ao parlamentar, tendo em vista a perda de sentido da figura de representante do povo livre, que por livre vontade e consciência delibera sobre toda sociedade. Em uma democracia de partidos, o deputado está submetido e atado à autoridade da agremiação a que se filia, estando obrigado a seguir as decisões acordadas por sua sigla. O que diferencia essa estrutura de um Estado autoritário é que neste o deputado não goza de influência alguma sobre as diretrizes escolhidas, enquanto naquela, ele pode colaborar ativamente na formação da vontade majoritária dos partidos. A ressalva é que, apesar de sua liberdade de atuação na esfera interna, externamente ele deve assegurar a homogeneidade essencial para a afirmação do partido, de modo a corroborar com as orientações da sigla em qualquer manifestação.

Quanto à responsabilidade do deputado por seu comportamento, na moderna democracia de partidos, ela é cada vez maior ante a agremiação, ao passo que é menos significativa ante os eleitores, cabendo, no lugar destes, aos partidos exigir dos parlamentares as obrigações assumidas ao se reunirem organizativamente e podendo, inclusive, excluir o deputado da organização. Desse modo, as instituições partidárias convertem-se em garantidoras da vontade popular, a qual se expressa por intermédio delas.
Aí reside a perda de autenticidade das eleições ao mesmo tempo em que se torna crescente a tendência plebiscitária que assumem. À medida que os cidadãos manifestam sua vontade política, escolhendo candidatos e programas oferecidos pelos partidos, o Estado democrático de partidos se concretiza, tendo em vista que ele tanto melhor funciona quanto maiores forem a participação e o envolvimento dos cidadãos ativos nas decisões plebiscitárias dos partidos.

Leibholz enfatiza que, na democracia de partidos, os assuntos mais caros à existência da nação devem ser decididos pelos próprios cidadãos. Essa recomendação se coaduna com a concepção de que os mandatários do governo são eleitos por conta da sua filiação ao partido, e não por sua personalidade e qualidades especiais. A identificação do eleitor se dá com o programa coletivamente construído e debatido na estrutura interna do partido, não com uma figura persuasiva. Nessa conjuntura, para que as diretrizes ideológicas sejam alteradas, é necessário um processo político intrapartidário amplo e democrático, que permita a efetiva participação do conjunto dos membros.

Nessas condições, é lícito afirmar que o sistema de sufrágio proporcional é um instituto do Direito Eleitoral concordante com a democracia de partidos e, portanto, correspondente ao Estado de partidos da democracia de massas. Afinal, ele favorece o desenvolvimento de partidos fortes e centralizados, assim como a concentração de poder político nos dirigentes do partido.

Para finalizar esse esboço, cabe destacar outra característica apontada por Naspolini (2006, p. 132), em que ele afirma que 
o Estado de partidos apresenta-se também como modelo político por excelência pluralista e, portanto, contrário a projetos políticos totalitários. Essa característica é uma consequência óbvia de um Estado que se pretende uma legítima democracia.

\section{Comprovação da imprescindibilidade do novo} paradigma para a efetivação da democracia

Com efeito, se não há democracia sem partidos, para que ela de fato se consolide é preciso que o Estado se configure como de partidos, de modo que a vontade estatal passe a ser constituída no interior dos partidos políticos, deslocando o eixo de decisão do parlamento para as organizações partidárias (MEZZAROBA, 2004, p. 158). Tendo em vista que só a interação entre o sistema de partidos e o sistema estatal pode concretizar a legitimidade e funcionalidade democráticas, o Estado democrático, portanto, deverá configurar-se como um Estado de partidos (GARCÍA-PELAYO, 1986, p. 85).

Vencido o ponto de que a democracia de nosso tempo é necessariamente estruturada em partidos políticos, essas agremiações devem ser assimiladas pelo Estado, precipuamente por meio da Constituição do país, como órgãos formadores da vontade estatal, de modo que as ações do governo estejam vinculadas ao partido (KELSEN, 1980, p. 198). Nesse contexto, García-Pelayo (1986, p. 90-91) destaca a influência dos partidos no sistema estatal à medida que os órgãos políticos funcionam como conversores da vontade dos partidos na vontade do Estado. Sob essa proporção, quanto mais eles são ocupados pelos mesmos partidos, menor é sua autonomia. Tal potencial de influência, segundo o autor, está diretamente relacionado aos resultados eleitorais (1986, p. 88).

Para tanto, os partidos são elevados ao status de "instituições jurídico-constitucionais" ao mesmo tempo em que se inserem na estrutura organizativa do Estado. Neste ponto, García-Pelayo (1986, p. 69) faz uma ressalva, apontando que essa condição não os torna órgãos políticos próprios do Estado, ao menos no sentido da "estatalidade organizada", tendo em vista a função que desempenham no processo de formação da vontade do Estado, já que em uma democracia tal vontade provém do povo até os órgãos do Estado - por intermédio dos partidos -, e não o contrário.

Ademais, os partidos que ocupam os órgãos do Estado não gozam de poder ilimitado, mas só podem atuar dentro da área que a Constituição prevê. A administração, por exemplo, não pode se identificar com o partido no poder. A sua função é, dentro do marco da Constituição, servir ao governo, abstraindo o partido que o ocupe, sob os princípios da legitimidade, neutralidade e imparcialidade. Isso também serve para a atividade jurisdicional.

A inserção dos partidos na Constituição implica o reconhecimento de que não são apenas organizações políticas e sociológicas, mas também organizações juridicamente relevantes. De fato, só a partir dessa penetração das agremiações no sistema estatal que as ações do Estado são convertidas em expressão dos anseios da maioria da população, daí a importância da consolidação de um Estado de partidos como corolário da democracia. 
Identificação do modelo na legislação e momento político brasileiros

Reconhecendo a verdade contida na afirmação de Naspolini (2006, p. 133), quando sustenta que um Estado de partidos em sua totalidade ainda não foi realizado em lugar nenhum do mundo, é importante destacar que o propósito desta lauda não será provar a vigência desse modelo de democracia de partidos no Brasil, mas apenas apresentar o ambiente jurídico favorável disponível atualmente na legislação brasileira para que esse modelo se consolide. Leibholz (1980, p. 214) corrobora esse entendimento observando que as situações das diversas democracias são muito distintas para que se possa falar de um reconhecimento geral do Estado de partidos.

O objetivo, na verdade, é atestar que - apesar da ciência de o Estado de partidos não surgir meramente a partir do momento em que são legalmente incluídos na disciplina jurídica das atividades eleitorais, mas quando de fato colaboram na formação de um novo modelo de organização política já é lícito afirmar que existe no Brasil o ambiente jurídico favorável e compatível com os requisitos elencados pela doutrina majoritária. De qualquer modo, embora ainda não realizado em sua inteireza, não se pode deixar de destacar uma certa tendência das democracias hodiernas rumo a esse modelo prefigurado pelo Estado de partidos. Nesse sentido, a constitucionalização de tais entes tem sido um primeiro passo.

Em tese, Mezzaroba (2004, p. 176-177) enuncia dois requisitos anteriores à sua implementação para que o modelo do Estado de partidos seja efetivamente adotado: que os partidos já tenham passado por seu processo de constitucionalização (reconhecidos constitucional e infraconstitucionalmente), e que esse reconhecimento constitucional inclua a declaração de sua importância fundamental para o sistema político democrático.

A Constituição Federal da República Brasileira cumpriu esses dois requisitos de forma explícita e incontestável, no seu artigo 17 (BRASIL, 1988), ao garantir a "liberdade de fusão, incorporação e extinção de partidos políticos", bem como no artigo $14, \S 3^{\circ}$, inciso $\mathrm{V}$, elencando a filiação partidária como condição de elegibilidade. O candidato não existe fora do partido político e nenhuma candidatura é possível fora de uma bandeira partidária. O Código Eleitoral, promulgado pela Lei $\mathrm{n}^{\circ} 4.737 / 1965$, corrobora esses princípios na redação do seu artigo $2^{\circ}$, no qual consta que:

Todo poder emana do povo e será exercido em seu nome, por mandatários escolhidos, direta e secretamente, dentre candidatos indicados por partidos políticos nacionais, ressalvada a eleição indireta nos casos previstos na Constituição e leis específicas (grifo do autor).

Da descrição de Leibholz exposta anteriormente, alguns requisitos também já são observáveis nos dispositivos que disciplinam as eleições no país. A própria afirmação de que "todo poder emana do povo" - constante do artigo $2^{\circ}$ do Código Eleitoral supracitado e repetida, 23 anos depois, na Constituição Federal da República em seu artigo $1^{\circ}$, parágrafo único - corresponde com a consequência elencada pelo autor de que, sob o paradigma democracia de partidos, o papel do público é ao mesmo tempo complementário e decisivo. 
No que concerne ao princípio da representação proporcional, aludida por Leibholz como instituto concordante com a estrutura do Estado de partidos, ela está prevista no Código Eleitoral Brasileiro, no artigo 84, para as eleições da Câmara dos Deputados, Assembleias Legislativas e Câmaras Municipais.

Outra consequência elencada por Leibholz, de que o deputado está submetido e atado à autoridade da agremiação a que se filia, encontra eco na Consulta $n^{\circ}$ $1.398 / 2007^{2}$ ao Tribunal Superior Eleitoral (TSE), cujo parecer assegurou, por maioria de seis votos a um, que os mandatos obtidos nas eleições, pelo sistema proporcional (deputados estaduais, federais e vereadores), pertencem aos partidos políticos ou às coligações, e não aos candidatos eleitos. Esse entendimento foi confirmado em nova consulta à corte, sob o $\mathrm{n}^{\circ} 1.423$ - dessa vez estendendo a deliberação sobre os mandatos de prefeitos, governadores e senadores - e convertido na Resolução $n^{\circ} 22.610$, no mesmo ano. Esse entendimento foi contestado pelo Partido Social Cristão (PSC) e pela Procuradoria-Geral da República nas Ações Diretas de Inconstitucionalidade (ADIs) $3999^{3}$ e 4086, diante do Supremo Tribunal Federal, que as declarou improcedentes e manteve a decisão do TSE em 2008.

Por fim, o caráter intrínseco desse modelo de Estado é sua vertente por excelência pluralista e antagônica a projetos totalitários. A Constituição do país recepciona esse princípio em dois momentos: ao eleger, em seu artigo $1^{\circ}$, como um dos fundamentos da República o pluralismo político e definir como preceito a ser resguardado pelas agremiações o pluripartidarismo.
Além desse preceito, a Constituição, no artigo 17 (BRASIL, 1988), estabeleceu que devem ser resguardados pelos partidos outros princípios: a soberania nacional, o regime democrático, o pluripartidarismo, os direitos fundamentais da pessoa humana, ter caráter nacional, não poder receber recursos financeiros de entidade ou governo estrangeiros ou de subordinação a estes, prestar contas à Justiça Eleitoral e funcionar no parlamento de acordo com a lei. Além disso, é vedada a utilização pelos partidos políticos de organização paramilitar.

Vale destacar que essa exigibilidade não vai de encontro à liberdade e à autonomia dos partidos políticos, imprescindíveis para a consolidação de uma democracia partidária. Pelo contrário, essas condições não passam de mecanismos para garantia da vigência do Estado de partidos, não limitações a ele. Afinal, a cobrança constitucional dos compromissos do partido com o regime democrático traduz de forma clara o rigoroso pressuposto democrático, e não um controle ideológico dos partidos.

Naspolini ainda destaca que:

[...] o Estado de partidos somente pode subsistir em um efetivo Estado Democrático de Direito, cujas normas jurídicas preservem certas esferas sociais da influência dos partidos políticos e disciplinem os direitos e deveres de tais agremiações, como o direito a liberdade externa, o direito as prestações públicas, a democracia interna dos partidos, etc. (2006, p. 134).

Mesmo que Mezzaroba (2004, p. 260261) observe que o atual modelo representativo brasileiro, ainda que democrático e de caráter partidário, não conduz aos preceitos fundantes de uma verdadeira democracia 
de partidos, a conjuntura política do país já aponta neste sentido. $\mathrm{O}$ próprio autor afirma que é extremamente significativa a redução da tradicional interferência do Estado sobre os partidos. Estado e partido, ao menos formalmente, distanciaram-se, isto é, o partido já não é mais concebido como parte integrante do Estado, como seu "apêndice político de legitimação". A conquista de tais liberdades descortina a possibilidade de um caminho a ser trilhado: o Estado de partidos.

\section{Considerações finais}

Ao enunciar no preâmbulo da Constituição o objetivo da reunião em Assembleia Nacional - "constituir um Estado Democrático" - e reiterar no artigo $1^{\circ}$ da Carta que a República Federativa do Brasil "constitui-se em Estado Democrático de Direito", o constituinte brasileiro elegeu o regime político do Estado. Entretanto, para que a democracia de fato se realize, como insistido ostensivamente em parágrafos anteriores, são necessários partidos políticos.

Como sustentáculo fundante da democracia moderna, os partidos políticos se fortalecem à medida que o princípio democrático se consolida. Essa afirmação é comprovada partindo do princípio de que o acesso dos indivíduos ao governo, como preconiza esse regime político, em uma sociedade de massas, só é possível quando os cidadãos, a fim de causar impacto na vontade coletiva, se reúnem em organizações definidas por fins políticos determinados.

Essas coletividades que agrupam vontades políticas coincidentes tomam a forma de partidos políticos. Articulado nas agre- miações, o povo cria o ambiente propício para a transação de interesses divergentes, cujo resultado culmina na formação da vontade geral, conduzindo o Estado em uma direção orientada e mediada.

$\mathrm{O}$ instrumento por meio do qual o indivíduo expressa seu interesse e contribui para a formação dessa vontade coletiva é o voto. Cabe aos partidos, portanto, reunir os afins em ideias para garantir-lhes influência eficaz no ritmo da vida pública. Afinal, o indivíduo isolado carece da capacidade de mobilização e de existência política ativa. Apenas com a reunião dos semelhantes é possível democratizar o acesso ao poder. Posicionar-se contra a Constituição de partidos significa, em última instância, colaborar para a hegemonia de um só grupo de interesses e impedir a construção de uma vontade legitimamente coletiva.

A digressão histórica sobre a trajetória política brasileira permitiu que fossem atadas pontas - nem sempre perceptíveis num desenvolvimento histórico atípico como o do Brasil - capazes de provar a veracidade dessa relação intrínseca entre democracia e partidos políticos. Há uma virtude em examinar tempo e espaço de forma comparativa: perceber padrões e rupturas, uma perspectiva que só a visão panorâmica e histórica pode proporcionar.

A história do Brasil é farta de momentos ilustrativos das ideias aqui expostas. A importância das agremiações é tanta, que tanto ditaduras quanto democracias cuidaram de institucionalizá-las, embora aquelas tinham criado critérios mais rígidos, como o Estado Novo e o regime militar. 
As ditaduras têm medo dos partidos políticos porque eles contêm em si o gérmen da democratização de qualquer sistema político. Por conta dessa natureza, o partido não deve ser organizado pelo Estado, mas pela sociedade, tendo autonomia para instrumentalizar seu próprio poder.

A verdadeira democracia é viável pela existência de uma pluralidade de partidos, que ofereçam ao eleitorado distintas opções. Não poderia haver limites para a representatividade, sendo que deveriam ser criados tantos partidos quanto fossem os segmentos de opinião da sociedade. Afinal, a legitimidade das agremiações deve ser coroada pela população, não imposta ou sufocada pela lei.

A falta de tradição democrática brasileira foi acompanhada senão do constante ataque aos partidos políticos, pelo menos de grave hostilidade à sua existência e funcionamento. Cada nova intervenção autoritária sempre se prevalecia da precariedade organizativa das instituições políticas, o que em si já era determinante para a imobilização a que de resto estava condenada a população em geral. A ausência de organizações políticas fortemente enraizadas na sociedade é característica marcante dos ambientes políticos de pouca ou nenhuma tradição democrática. O entendimento de fortalecer líderes em detrimento das instituições políticas apresenta-se como traço marcante em toda história jurídico-política do Brasil.

Quando os partidos são fortes, em vez de deslumbramento com personalidades pretensamente salvadoras, há o enraizamento social de concepções e ideologias racionalmente arquitetadas, que atendem ao bem comum e moralizam o poder. A ne- gociação e o conluio é muito mais fácil com lideranças descomprometidas com pautas programáticas do que com partidos, ainda mais se estes são constituídos interna e externamente do modo mais democrático possível. Um partido bem organizado coíbe as más práticas eleitorais porque está sob a vigilância de muitas pessoas. Privilegiam-se interesses coletivos e há identificação com ideias, não imagens.

Dessa triagem percorrida, o momento político inaugurado pela Constituição de 1988 foi o mais efetivo passo em direção à institucionalização universalizada dos direitos políticos e também dos partidos. Não é à toa que a partir dela o ambiente jurídico propício à instalação de um Estado de partidos começa a ser cultivado.

A democracia partidária é a última etapa do processo de reconhecimento jurídico dos partidos políticos e surge a partir do momento em que eles, além de legalizados e incluídos na ordem Constitucional do país, colaboravam efetivamente para a formação de um novo modelo de organização política.

Não se trata, portanto, de apenas incorporá-los ao aparato estatal, mas de evoluir qualitativamente o reconhecimento jurídico ao ponto de declarar, explicitamente, a imprescindibilidade das funções assumidas pelas agremiações para a legitimidade democrática do Estado. O reconhecimento constitucional da importância que assumem no sistema estatal é o alicerce para a consolidação desse novo modelo de Estado.

O Brasil galgou esse passo com a Constituição cidadã de 1988, à qual se somaram outros dispositivos tendentes à afirmação do novo modelo de democracia. Para efetivar o 
arquétipo, são necessários partidos com adequada capacidade organizativa e comprometimento político, de modo a satisfazerem as demandas e esperanças dos eleitores.

Vinte e cinco anos depois da promulgação da Constituição, o Brasil é ainda uma democracia jovem. Apesar de contar com um sistema partidário plural, composto de 32 agremiações registradas no Tribunal Superior Eleitoral, é notório que uma vasta maioria delas existe apenas como veículo de interesses privados e do clientelismo. Com esses velhos vícios, a proliferação de partidos não é indicativo da saúde do sistema. Entretanto, quando novas agremiações surgem para propor e apoiar novas ideias e práticas, então elas podem servir para desenvolver a democracia do país. Os partidos escolhem seus candidatos antes de os eleitores irem às urnas, por isso é essencial que eles funcionem com transparência e eficiência, de fato comprometidos com o nobre propósito a que se destinam.

Se o eleitor puder se deparar com instituições partidárias empenhadas por esse ideal, ele não se deixará mais envolver por figuras carismáticas e demagógicas, mas depositará sua fidúcia em programas democraticamente escolhidos e debatidos, e cujos fiadores são todos os membros do partido, de modo que sua confiabilidade é muito mais segura e efetiva.

De toda feita, o processo de construção da democracia não tem fim. É permanente, contínuo e diretamente dependente da vontade política e da participação dos cidadãos. Felizmente, no contexto político e jurídico atual, vivemos o momento histórico mais propício à realização da democracia partidária.
Sem olvidar do fato de que essa é uma conquista diária, a ser renovada e confirmada a cada eleição, e dependente não só dos dizeres de uma Constituição, mas da consciência e postura dos cidadãos, é lícito dizer que o Brasil conta hoje com o ambiente jurídico favorável para a concretização de um Estado de partidos.

\section{Abstract}

With the purpose to prove the theoretical link between Democracy and Political Parties in the modern mass society, the article focuses on these two figures of Political Science, describing them since their conceptualization, indicating the causes of this connection and the functions that the associations redeem in this government scheme. Shifting the investigation to the empirical plan, the Brazilian political experience is narrated with emphasis in the trajectory of the parties until their wide reception by the law, in order to corroborate the parallel between the institutionalization of the Parties and the fortification of Democracy. The last stage of this process - the adoption of plebiscitary democracy in the modern State of Parties - concur with the last section of the article, where the analysis focus attention on the confrontation among the requirements of the majority doctrine to the effectiveness of this model and the current political and juridical context of Brazil - the last effort to demonstrate in which direction the consolidation of Brazilian democracy moves to.

Keywords: Democracy. Political Parties. State of Parties. 


\section{Resumen}

Resumen: Con el propósito de probar el nexo teórico entre Democracia y Partidos Políticos en la moderna sociedad de masas, el artículo se ocupa de estas dos figuras de la Ciencia Política, describiéndolas desde su conceptualización, señalando las causas de esta conexión e las funciones que desempeñan las agremiaciones en este régimen de gobierno. Moviendo la investigación para el plano empírico, la experiencia política brasileña es narrada con énfasis en la trayectoria de los Partidos hasta su amplia recepción por el sistema legal, con el fin de corroborar el paralelo entre la institucionalización de los Partidos y el fortalecimiento de la democracia. La ultima etapa de esto proceso - la adopción de la democracia plebiscitaria en el moderno Estado de partidos - coincide con la ultima sección del artigo, donde la análisis se centra en el confronto entre los requisitos de la doctrina mayoritaria para la efectuación de esto modelo, e la coyuntura política e jurídica actúale del Brasil - como el ultimo esforzó de demostrare en cual direccione camina la consolidación de la democracia brasileña.

Palabras clave: Democracia. Partidos Políticos. Estado de partidos.

\section{Notas}

Código Civil de Clóvis Beviláqua.

TRIBUNAL SUPERIOR ELEITORAL. Pedido de decretação de perda cargo eletivo de vereador. Desfiliação partidária. Datas divergentes. Validade. Comunicação ao cartório eleitoral. Inteligência do art. 21, parágrafo único do art. 22, ambos da lei $n^{0}$ 9.096/95. Certidão. Decisão que reco- nheceu a desfiliação ocorrida após 27/03/2007 (consulta TSE $n^{\circ} 1.398$ ). Preliminares de impossibilidade jurídica, decadência e ilegitimidade passiva rejeitadas. Grave discriminação pessoal não comprovada. Mudança substancial do conteúdo programático não caracterizada. Ausência de justa causa. Exclusão dos suplentes citados. Pedido julgado procedente. Decisão por maioria. 1. Nos termos dos arts. 21, 22, parágrafo único, ambos da Lei $n^{\circ}$ 9.096/95, o cancelamento da filiação partidária consuma-se com a comunicação ao Juiz Eleitoral da Zona em que for inscrito o filiado. 2. Havendo dúvida quanto à data de desfiliação do filiado, prevalece aquela constante da comunicação recebida pela Justiça Eleitoral. 3. Inexistindo quaisquer das hipóteses previstas na Resolução TSE $n^{\circ} 22.610 / 2007$, ensejadoras de justificação para a desfiliação, impõe-se a decretação da perda do mandato do titular em face da infidelidade partidária. Consulta $\mathbf{n}^{0} \mathbf{1 . 3 9 8}$, de 27 de março de 2007.

3 EMENTA: Ação direta de inconstitucionalidade. Resoluções do tribunal superior eleitoral $\mathrm{n}^{\circ}$ 22.610/2007 e $\mathrm{n}^{\mathrm{o}}$ 22.733/2008. Disciplina dos procedimentos de justificação da desfiliação partidária e da perda do cargo eletivo. Fidelidade partidária. 1. Ação direta de inconstitucionalidade ajuizada contra as Resoluções $n^{\circ} 22.610 / 2007$ e $\mathrm{n}^{\mathrm{o}} 22.733 / 2008$, que disciplinam a perda do cargo eletivo e o processo de justificação da desfiliação partidária. 2. Síntese das violações constitucionais arguidas. Alegada contrariedade do art. $2^{\circ}$ da Resolução ao art. 121 da Constituição, que ao atribuir a competência para examinar os pedidos de perda de cargo eletivo por infidelidade partidária ao TSE e aos Tribunais Regionais Eleitorais, teria contrariado a reserva de lei complementar para definição das competências de Tribunais, Juízes e Juntas Eleitorais (art. 121 da Constituição). Suposta usurpação de competência do Legislativo e do Executivo para dispor sobre matéria eleitoral (arts. 22, I, 48 e 84 , IV da Constituição), em virtude de o art. $1^{\circ}$ da Resolução disciplinar de maneira inovadora a perda do cargo eletivo. Por estabelecer normas de caráter processual, como a forma da petição inicial e das provas $\left(\operatorname{art.} 3^{\circ}\right)$, o prazo para a resposta e as consequências da revelia (art. $3^{\circ}$, caput e par. ún.), os requisitos e direitos da defesa (art. $\left.5^{\circ}\right)$, o julgamento antecipado da lide (art. $\left.6^{\circ}\right)$, a disciplina e o ônus da prova (art. $7^{\circ}$, caput e par. ún., art. $8^{\circ}$ ), a Resolução também teria violado a reserva prevista nos arts. 22, I, 48 e 84, IV da Constituição. Ainda segundo os requerentes, o texto impugnado discrepa da orientação firmada pelo Supremo 
Tribunal Federal nos precedentes que inspiraram a Resolução, no que se refere à atribuição ao Ministério Público eleitoral e ao terceiro interessado para, ante a omissão do Partido Político, postular a perda do cargo eletivo $\left(\operatorname{art} .1^{\circ}, \S 2^{\circ}\right)$. Para eles, a criação de nova atribuição ao MP por resolução dissocia-se da necessária reserva de lei em sentido estrito (arts. 128, $\S 5^{\circ}$ e 129 , IX da Constituição). Por outro lado, o suplente não estaria autorizado a postular, em nome próprio, a aplicação da sanção que assegura a fidelidade partidária, uma vez que o mandato "pertenceria" ao Partido. Por fim, dizem os requerentes que o ato impugnado invadiu competência legislativa, violando o princípio da separação dos poderes (arts. $2^{\circ}, 60, \S 4^{\circ}$, III da Constituição). 3. O Supremo Tribunal Federal, por ocasião do julgamento dos Mandados de Segurança 26.602, 26.603 e 26.604 reconheceu a existência do dever constitucional de observância do princípio da fidelidade partidária. Ressalva do entendimento então manifestado pelo ministro-relator. 4 . Não faria sentido a Corte reconhecer a existência de um direito constitucional sem prever um instrumento para assegurá-lo. 5. As resoluções impugnadas surgem em contexto excepcional e transitório, tão-somente como mecanismos para salvaguardar a observância da fidelidade partidária enquanto o Poder Legislativo, órgão legitimado para resolver as tensões típicas da matéria, não se pronunciar. 6 . São constitucionais as Resoluções 22.610/2007 e 22.733/2008 do Tribunal Superior Eleitoral. Ação direta de inconstitucionalidade conhecida, mas julgada improcedente.

\section{Referências}

BRASIL. Ato Institucional $n^{\circ} 2$, de 27 de outubro de 1965.

- Constituição da República dos Estados Unidos do Brasil, de 24 de fevereiro de 1891.

. Constituição da República dos Estados Unidos do Brasil, de 16 de julho de 1934.

Constituição da República Federativa do Brasil. Brasília, DF: Senado Federal: Centro Gráfico, 1988.

. Constituição dos Estados Unidos do Brasil, de 10 de novembro de 1937.
. Constituição dos Estados Unidos do Bra-

sil, de 18 de setembro de 1946.

Constituição do Império do Brasil, de 25 de março de 1824.

. Decreto $n^{0} 21.076$, de 24 de fevereiro de 1932.

. Decreto-Lei $n^{\circ} 37$, de 2 de dezembro de

1937.

1945.

Decreto-Lei $n^{\circ} 7586$, de 28 de maio de

Emenda Constitucional $n^{\circ} 25$, de 15 de maio de 1985.

. Emenda Constitucional $n^{\circ} 11$, de 30 de abril de 1996.

. Lei $n^{\circ} 3.071$, de 1 de janeiro de 1916.

. Lei $n^{\circ} 4737$, de 15 de julho de 1965.

. Lei $n^{\circ} 4740$, de 15 de julho de 1965.

. Lei $n^{\circ} 5682$, de 21 de julho de 1971.

1979.

. Lei $n^{\circ}$ 6767, de 20 de dezembro de

CHACON, Vamireh. História dos partidos brasileiros. 2. ed. rev. amp. Brasília: Universidade de Brasília, 1985. p. 23.

GAMBINO, Silvio. Relaciones entre sistema electoral, formato de partidos y forma de gobierno em la experiencia parlamentaria española. Revista de Estudios Políticos, Madrid, v. 4, n. 146, oct.-dic. 2009. p. 11-47.

GARCÍA-PELAYO, Manuel. El Estado de partidos. Madrid: Alianza, 1986.

KELSEN, Hans. Formación de la voluntad en la democracia moderna. In: LENK, Kurt; NEUMANN, Franz (Org.). Teoria e sociologia críticas de los partidos politicos. Trad. Ignacio de Otto. Barcelona: Anagrama, 1980. p. 197-204.

LEIBHOLZ, Gerhard. Representacion y identidad. In: LENK, Kurt; NEUMANN, Franz (Org.). Teoría e sociología críticas de los partidos políticos. Trad. Ignacio de Otto. Barcelona: Anagrama, 1980. p. 205-227. 
LEONI, Francesco. El partido como grupo social. Revista de Estudios Políticos, Madrid, v. 2, n. 68, p. 283-296, abr.-jun. 1990.

MELO FRANCO, Afonso Arinos de. História e teoria dos partidos políticos no Brasil. 3. ed. São Paulo: Alfa-Omega, 1980.

MEZZAROBA, Orides; MONTEIRO, Cláudia Servilha. Introdução ao direito partidário brasileiro. 2. ed. rev. Rio de Janeiro: Lumen Juris, 2004. $347 \mathrm{p}$.

MONTERO, José Ramon; GUNTHER, Richard. Los estudios sobre los partidos políticos: una revisión crítica. Revista de Estudios Políticos, Madrid, v. 4, n. 118, p. 9-38, oct.-dic. 2002.

NASPOLINI, Samuel Dal-Farra. Pluralismo político: subsídios para análise dos sistemas partidário e eleitoral brasileiros em face da Constituição federal. Curitiba: Jurua, 2006. 319 p.

SUPREMO TRIBUNAL FEDERAL. Ação Direta de Inconstitucionalidade (ADI) 3999, de 12 de novembro de 2008.

SUPREMO TRIBUNAL FEDERAL. Ação Direta de Inconstitucionalidade (ADI) 4086, de 12 de novembro de 2008.

TRIBUNAL SUPERIOR ELEITORAL. Consulta $n^{\circ}$ 1398, de 27 de março de 2007.

TRIBUNAL SUPERIOR ELEITORAL. Consulta $n^{\circ}$ 1423, de 27 de março de 2007.

TRIBUNAL SUPERIOR ELEITORAL. Resolução $n^{\circ} 22.610$, de 25 de outubro de 2007.

VIEIRA, Reginaldo de Souza. Partidos políticos brasileiros: das origens ao princípio da autonomia político-partidária. 2002. Dissertação (Mestrado em Direito) - Programa de Pós-Graduação em Direito. Universidade Federal de Santa Catarina, Centro de Ciências Jurídicas. Florianópolis, 2002.

ZAMPETTI, Pier Luigi. Del Estado Liberal al Estado de partidos: la representación política. Trad. Virgilio J. Loiacano. Buenos Aires: Ediar, 1969. 